\title{
TEORIA DAS ORGANIZAÇÕES
}

Esta é, provavelmente, a área mais abrangente no campo da Administração. Em princípio, tudo pode ser estudado em um curso de Teoria das Organizações, ou simplesmente Organizações: poder, tecnologia, relações de trabalho, cultura organizacional, estrutura, imaginário, simbolismo, comportamento, análise e crítica organizacional. O que pode ser um campo extremamente atraente e amplo para uns, gerador de reflexão, pode se constituir, para outros, em uma dificuldade de síntese e falta de identidade, pois se existe uma área da Administração marcada pela diversidade de abordagens e perspectivas é, certamente, esta. Acreditamos que a área dá o exemplo de que ausência de consenso é resistência à conformidade, à pasteurização e à uniformidade. Não se pode amordaçar a reflexão. Os livros escolhidos por Maria Ester de Freitas, Professora da FGVEAESP, - buscam contemplar diferentes olhares e representam uma escolha entre tantas outras.

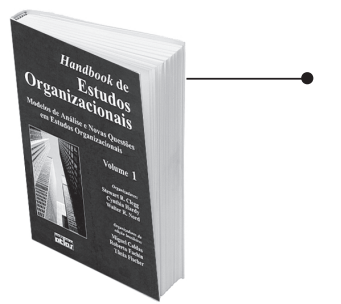

HANDBOOK DE ESTUDOS ORGANIZACIONAIS Stewart Clegg, Cynthia Hardy e Walter Nord (Orgs.). [Organização da edição brasileira: Miguel Caldas, Roberto Fachin e Tânia Fischer]. São Paulo : Atlas, 1998. 466 p.

Lançados já os volumes 1 e 2 de um conjunto de três livros, esse handbook traz toda a riqueza da produção acadêmica norte-americana na área. O volume 1 é dedicado aos modelos de análise organizacional, a partir da teoria da contingência, e temas emergentes. O volume 2 traz as novas reflexões e direções da área, a discussão do processo e dos novos objetos de pesquisa. Todos os capítulos originais são comentados por autores brasileiros reputados. É um empreendimento valioso. Mais apropriado aos cursos de pós-graduação, o handbook é uma fonte de referências para diversos temas e subáreas da Teoria das Organizações.

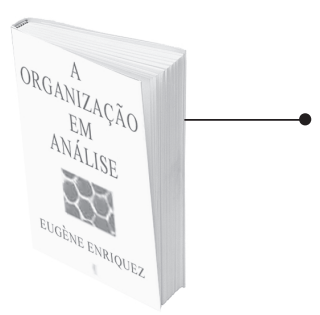

A ORGANIZAÇÃo EM ANÁLISE Eugène Enriquez. Petrópolis : Vozes, 1997. 302 p.

O autor entende a organização como um sistema que é, ao mesmo tempo, simbólico, imaginário e cultural. Ancorado na perspectiva psicossociológica, que incorpora a contribuição freudiana aos estudos organizacionais, Enriquez apresenta com detalhes sete instâncias de análise das organizações.. Não se pretende psicanalizar as organizações, mas entendê-las como espaço do homem e lugar onde ele se manifesta inteiro: com seus sonhos, medos e paixões, além da racionalidade necessária ao empreendimento organizacional. Em Enriquez, nessa e em outras obras, o homem é sempre tratado com o respeito que merece.

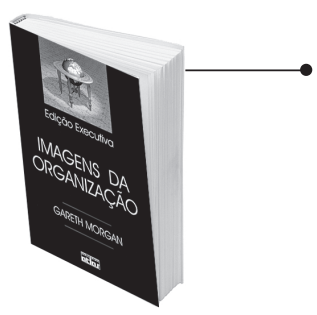

IMAGENS DA ORGANIZAÇÃO Gareth Morgan. São Paulo : Atlas, 1996. 421p.

Considerado já um clássico, apesar de sua publicação original datar apenas de 1986, o livro continua sendo um best-seller mundial. O autor foi muito feliz em sua escolha de metáforas para interpretar as organizações, dando uma leveza a um tema tão denso. Eventualmente, pode-se criticar o autor pela diversidade de propostas para análise, porém não se trata de um trabalho leviano; essa diversidade é própria do campo e nenhuma abordagem é excludente, o que reflete a própria multiplicidade do objeto. Obviamente, algumas metáforas são mais apropriadas a determinados formatos organizacionais e momentos históricos. No entanto, elas dão uma indicação da complexidade do objeto estudado.

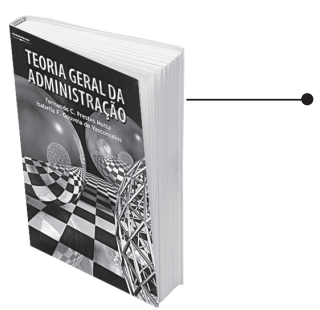

TEORIA GERAL DA ADMINISTRAÇÃo Fernando C. Prestes Motta e Isabella F. Gouveia de Vasconcelos. São Paulo : Thomson, 2002. $411 \mathrm{p}$.

Trata-se de um livro primoroso, que traz a marca do maior teórico organizacional brasileiro, Prestes Motta, que, aliado ao entusiasmo de Isabella Vasconcelos, faz uma arqueologia do saber organizacional. Após situar o campo, os autores mergulham no túnel do tempo para resgatar Taylor e todos os clássicos, fazer um passeio pelo século XX e chegar a um, ainda, indefinido movimento pós-moderno. Este livro diferencia-se dos demais em especial, em sua organização temática e na valiosa bibliografia que foge ao narcisismo da produção norte-americana. É um livro maduro, que

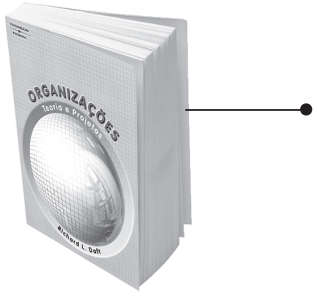
reflete bem o campo, as encruzilhadas, as peculiaridades do objeto organizacional.

ORGANIZAÇÕES - Teoria e projetos Richard L. Daft. Tradução: Cid Knipel Moreira. São Paulo : Thomson, 2002.

$532 \mathrm{p}$.

Traduzido da sétima edição norte-americana, cujo título é Organization Theory and Design, Daft, nessa nova edição, faz uma grande atualização de seu livro-base para incluir novos temas, novos casos, novos exemplos e até um glossário. É um livro-texto e, como é comum nos EUA, traz uma mescla da teoria e prática, com ilustrações de casos de grandes empresas para dar maior consistência à análise e perguntas para dirigir discussões de grupos. Um livro na melhor tradição funcionalista da área, ou seja, centrado na preocupação de resolver problemas. 